The Antecedents and Consequences of Value CoCreation Behaviors in a Hotel Setting: A TwoCountry Study Roy, S.K., Balaji, M.S., Soutar, G., Jiang, Y.

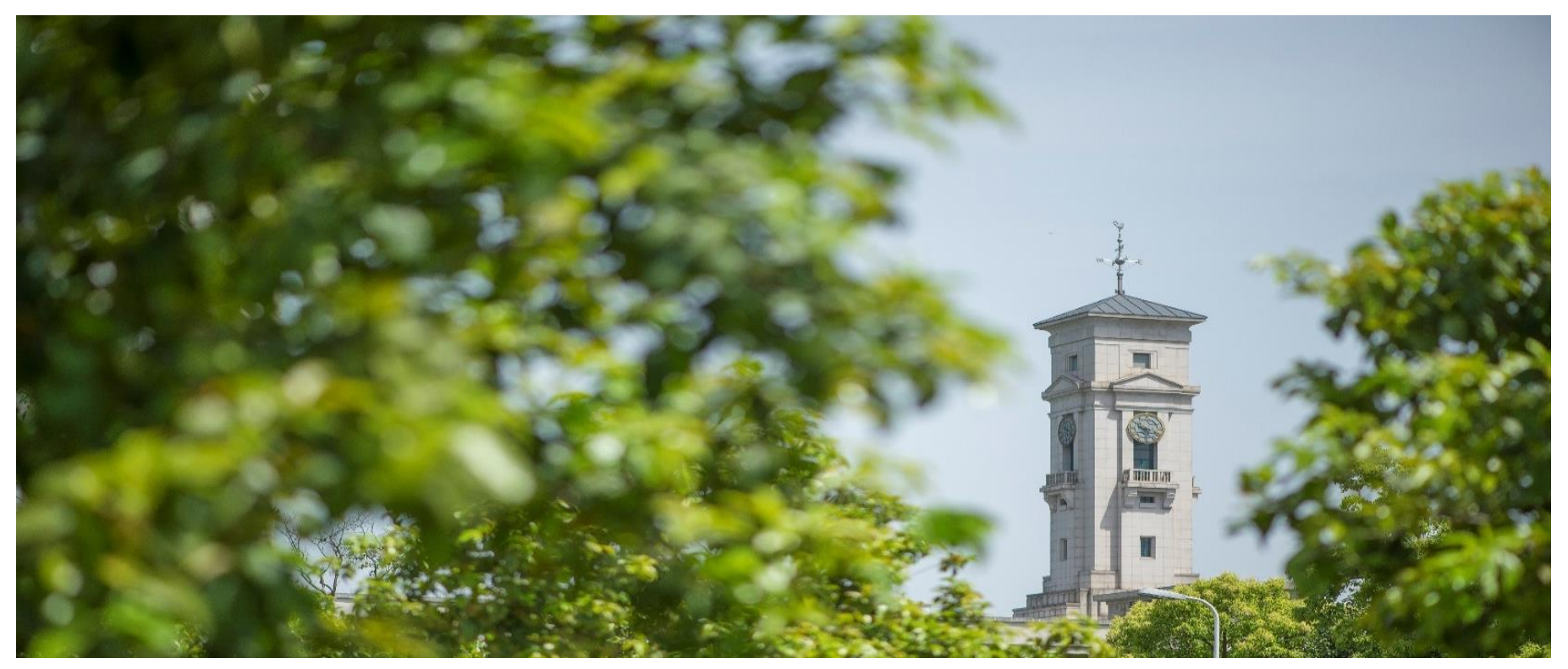


University of Nottingham Ningbo China, 199 Taikang East Road, Ningbo, 315100, Zhejiang, China.

First published 2019

This work is made available under the terms of the Creative Commons Attribution 4.0 International License:

http://creativecommons.org/licenses/by/4.0

The work is licenced to the University of Nottingham Ningbo China under the Global University Publication Licence:

https://www.nottingham.edu.cn/en/library/documents/researchsupport/global-university-publications-licence.pdf 


\title{
THE ANTECEDENTS AND CONSEQUENCES OF VALUE CO-CREATION BEHAVIORS IN A HOTEL SETTING: A TWO-COUNTRY STUDY
}

\begin{abstract}
This study examines the antecedents and consequences of value co-creation behavior in a hospitality context. An online questionnaire with samples of hotel patrons in the US and Australia was used to obtain data and Partial Least Square modeling was used in the analysis. The results suggest patron fairness perception enhances trust and identification with a hotel, which encourage engagement in the value co-creation behavior. Further, this behavior enhances patron wellbeing and respect for the hotel. The study contributes to the literature by suggesting a value co-creation behavior model in the hospitality context and empirically examining the antecedents and consequences of this behavior. The results have important implications for managers designing service encounters that can encourage hotel patrons to engage in the value co-creation behavior.
\end{abstract}

Keywords: Value co-creation behavior; service fairness; respect; wellbeing; trust; hotels 


\section{Introduction}

Practitioners and academics have recognized the blurring of roles between customers and service providers (Im \& Qu, 2017). More and more, service providers focus on collaborating with customers in co-creating unique value and delivering exceptional experiences. Value cocreation is especially important for the hotel industry because the survival and growth of hotels depend largely on creating and offering unique, memorable, and personalized experiences for their customers. Unsurprisingly, hotels that focus on value co-creation and customer experience outperform competitors and report higher revenues. According to a recent report, hotel customers are willing to pay 14 percent premium for a personalized experience (PWC, 2018). Similarly, hotels that provide superior customer experiences earn 5.7 times more revenue than others (Morgan, 2019). In response to this, several hotels have shifted from a business-oriented viewpoint to a customer-centric, value co-creation perspective to enhance customer value and experience (Chathoth et al., 2013). For example, Hilton leverages technology to co-create value with customers. Customers can choose the room and floor they want, order the meal ahead of time, and personalize how they would like to be welcomed (Kontzer, 2016). Similarly, Marriott harnesses the information that guests share about themselves, such as the hobby and the pillow type preference, to customize the guest experience and positively surprise them (Bova, 2018).

As value co-creation involves joint efforts of the customer and the service provider, customer engagement in this process is critical to its success (Chathoth, Ungson, Harrington, \& Chan, 2016). The customer's actual engagement in the value co-creation process is termed as value co-creation behavior (VCCB). It is a micro-level phenomenon that represents the interaction between the customer and the service provider during the value co-creation process (Laud \& Karpen, 2017). VCCB manifests a series of customer-led participation and citizenship 
behaviors such as information sharing, information seeking, feedback, helping, tolerance, responsible behavior, personal interaction, and advocacy that customers perform during the value co-creation process (Yi \& Gong, 2013). An understanding of VCCB can help service providers improve service interactions, strengthen the relationship with customers, as well as increase customer satisfaction and loyalty (Laud \& Karpen, 2017; Tommasetti, Troisi, \& Vesci, 2019). However, VCCB is a relatively new concept that has received scant attention in the academic research, especially in the hotel industry. In response to this, there are recent calls for more systematic evidence on VCCB in hospitality settings (Chathoth et al., 2013; Ahn, Lee, Back, \& Schmitt, 2019). Furthermore, given the benefits of VCCB, hotels must recognize what factors drive customers to perform VCCB and understand the possible consequences of engaging in this behavior. These insights should help hotel managers develop strategies to enable and encourage value co-creation among its customers. Therefore, the primary objective of this study is to examine the antecedents and consequences of VCCB in the hotel industry.

The contributions of this study are threefold. Firstly, prior hospitality research focuses on the conceptual understanding of the value co-creation process (Chathoth et al. 2013; Camilleri \& Neuhofer, 2017). It seems that hotel patrons are willing to participate and co-create value and that value co-creation enables hotels to achieve a competitive advantage (Harkison, 2018). However, the ways in which patrons participate and the effects of such behaviors have received limited empirical attention, which is unfortunate as an investigation of VCCB is likely to help improve customer experiences and strengthen their relationships with the hotel.

Secondly, this study focuses on antecedents and outcomes that have rarely been investigated before but are necessary to consider in relation to VCCB (Laud \& Karpen, 2017). Perceived service fairness, trust, and customer-company identification are examined as key 
antecedents to patrons engaging in the VCCB in the present study. Fairness, trust, and identification are key elements of any customer-brand relationship and since value co-creation involves collaborative exchanges between the service provider and the patron, they are expected to play a critical role in determining VCCB. Understanding relationships between these constructs and VCCB may help researchers and hotel managers better understand the processes through which patrons evaluate hotel experiences and collaborate to co-create value. Specifically, we suggest fairness perceptions build trust (Wirtz \& Lwin, 2009) and improve patron identification with the hotel (So, King, Sparks, \& Wang, 2013), which lead to VCCB. In this way, the present study answers Chou, Lin and Huang (2016)'s call for research to examine the mechanisms through which fairness influences value co-creation.

Another contribution of this study lies in examining the individual and organizational outcomes of VCCB. We focus on subjective wellbeing and perceived respect as outcomes of VCCB in this study due to the following reasons. First, there has been growing interest in delivering superior value that maintains or improves customer wellbeing (Sharma, Conduit, \& Hill, 2017). Second, in hotel industry, a well-respected brand or organization strengthens the customer's confidence and enhances customer loyalty (Jin, Lee, \& Huffman, 2012). However, studies of customer respect as an outcome of value co-creation are scant. To advance the understanding of hotel guests' subjective wellbeing and perceived respect, we investigate whether participation in co-creation processes would improve patrons' wellbeing and increase their respect for the hotel.

\section{Theoretical Background and Hypothesis Development}

There is a heavy reliance on the service-dominant logic (SDL) to understand and examine VCCB. However, Grönroos (2011) argues that without an understanding of the 
service provider-customer interaction, it is hard to examine VCCB, especially as Payne, Storbacka and Frow (2008) noted critical service provider-customer encounters can influence customers' VCCBs positively or negatively. Thus, organizations need to identify opportunities that lead to positive service encounters. Similarly, organizations need to monitor and resolve negative service encounters, which will hinder customers' VCCBs. Hence, we adopt SDL as a framework to understand and examine VCCB. In addition, the study's model, shown in Figure 1, comes from an examination of equity theory (Adams, 1963), social exchange theory (Blau, 1964), and social identity theory (Fisher, McPhail, \& Menghetti, 2010). We suggest that, for VCCB to occur, hotels need to offer fair services that establish trust and customer identification. Without fair services, patrons experience negative emotions that reduce trust and compliance behaviors ( $\mathrm{Su}, \mathrm{Swanson}, \& \mathrm{Chen}$, 2016). When fair services are offered, patrons engage in VCCBs, which lead to greater respect for the hotel and an improvement in patrons' wellbeing. The following sections outline these suggested relationships in more detail.

[Insert Figure 1 about here]

\section{Perceived Service Fairness}

Service fairness is the extent to which patrons perceive fairness or justice in a service provider's behavior (Namkung \& Jang, 2010). Patrons are likely to collaborate with a provider who is regarded as fair (Shulga, Busser, \& Kim, 2018). Equity theory suggests encounters will be perceived as fair when the ratio of outcomes (experiences) to inputs (effort, money, time) is comparable with the ratio of other such encounters (Adams, 1963). When patrons feel they have been treated unfairly, they will attempt to restore equity by reducing the quality or quantity of their outputs. Fairness is a readily available and effective 
mechanism for people dealing with service interactions (Kwortnik \& Han, 2011; Su, Swanson, \& Chen, 2016), such as those that occur in the hotel context.

Traditionally, fairness is viewed as a four-dimensional construct, with distributive, procedural, interpersonal, and informational fairness aspects. Distributive fairness is a perception of the outcomes received, while procedural fairness is a perception of fairness in a provider's processes. Interpersonal fairness is the extent to which a provider treats customers with dignity during service exchanges, while informational fairness relates to the adequacy of communication and information provided by a provider.

While prior studies suggest that patrons evaluate these dimensions during encounters (e.g. Namkung \& Jang, 2010; Nikbin, Marimuthu, \& Hyun, 2016), some have criticized this idea, suggesting customers form holistic impressions of fairness. For example, Törnblom and Vermunt (1999, p. 51) suggested individual fairness dimensions may be meaningful only in relation to the overall fairness of an encounter, as "people conceive the fairness of a situation as gestalt". Similarly, Beugre and Baron (2001) argued that the fairness dimensions provide a basis for forming an overall perception of being treated fairly, while DeWitt, Nguyen and Marshall (2008, p. 270) suggested customers "arrive at an overall perception of justice." Further, studies have shown fairness dimensions are strongly correlated (e.g. Kim, Kim, \& Kim, 2009; Chen et al., 2015).

Consequently, service fairness is modeled as a second-order formative construct with distributive, procedural, interpersonal, and informational fairness dimensions. We use a formative approach as the dimensions are distinct and not interchangeable (Chiu, Huang, \& Yen, 2010). Thus, service fairness is considered as an overall evaluation based on its four 
dimensions, which should provide a comprehensive understanding of how patrons form fairness evaluations following hotel service encounters.

\section{Value co-creation behaviors}

Value co-creation is the "benefit realized from (the) integration of resources through activities and interactions with collaborators in the customers' service network" (McCollKennedy et al., 2012, p. 375). It represents a series of activities customers perform during service exchanges to achieve desired outcomes. Yi and Gong (2013) called these activities 'value cocreation behaviors' and suggested two dimensions namely 'customer participation behavior' and 'customer citizenship behavior'. In the hotel context, customer participation behavior is an inrole behavior that is expected and required, while customer citizenship behavior is an extra-role behavior, which is discretionary efforts directed toward the hotel and others. When patrons go beyond their participation activities and engage in citizenship behavior, they provide extraordinary value to the hotel that helps build a competitive advantage (Choi \& Kim, 2013).

Although prior studies underscore the importance of in-role and extra-role behaviors separately (Choi \& Kim, 2013; Chen et al., 2015), few hospitality researchers have integrated both types of VCCB. This study examines a comprehensive value co-creation model by including customer participation behavior and citizenship behavior. Examining their antecedents and outcomes should provide valuable insights into how to stimulate patrons' VCCBs.

Customer participation behavior has four underlying dimensions. First, patrons seek information to understand the services they are going to receive and their roles and tasks in the value co-creation process. By seeking information, either directly by asking or indirectly through informational cues, patrons reduce uncertainty and develop the knowledge and skills that help resource integration (Lee, Hsiao, \& Chen, 2017). Second, patrons need to share information with 
a provider if they are to co-create meaningful and memorable experiences. According to Yi and Gong (2013), information sharing is essential to the success of value co-creation, as employees will not know how to perform their duties to meet customer expectations if customers fail to provide accurate information. Through information sharing, patrons discuss their needs, concerns and ideas, as well as the services to be received (Taheri, Coelho, Sousa, \& Evanschitzky, 2017). Third, for successful value co-creation, patrons must recognize their roles and cooperate by following guidelines, policies, and directions. By accepting their role as "partial employees," patrons can participate efficiently in co-creating value (Liu \& Tsaur, 2014). Finally, personal interactions between patrons and hotels also play a role, as value co-creation is more likely when such interactions are courteous, warm, and friendly (Golubovskaya, Robinson, \& Solnet, 2017). Customer citizenship behavior also has four dimensions, namely feedback, advocacy, helping, and tolerance. Feedback includes the solicited and unsolicited information patrons provide to a hotel about the services received. By providing feedback, patrons play a key role in improving services and co-creating value for the hotel (Navarro, Llinares, \& Garzon, 2016). Advocacy refers to the tendency of patrons to recommend the hotel to others. Advocacy, a strong form of positive word-of-mouth, can be seen in a patron's promotion and defense of a service provider (Lee et al., 2017). Helping reflects the willingness of the patrons to give information or assistance about the hotel to others. By assisting others, patrons display a sense of empathy and social responsibility toward the hotel (Xie, Peng, \& Huan, 2014). Lastly, tolerance refers to the willingness of patrons to forgive a hotel when service outcomes do not match expectations. Tolerance can prevent patrons from switching to other providers (Swanson \& Hsu, 2009). In line with Yi and Gong's (2013) suggestion, VCCB is conceptualized as a third-order construct, with 
participation and citizenship behaviors modeled as formative second-order constructs determined by eight first-order reflective dimensions.

\section{Perceived respect}

There is no clear definition of 'respect', although it is often described in terms of the nature of the treatment customers receive during service encounters or in terms of customers' beliefs about and attitude toward a provider. Here, the latter perspective is adopted, as we are interested in understanding how VCCB shapes relational and personal outcomes. As SDL involves resource integration (Vargo \& Lusch, 2004), patron willingness to share resources during the value co-creation process depends on the extent to which they appreciate the contributions a hotel (provider) makes in co-creating memorable and unique customer experiences. The worth accorded to a hotel contributes to the development of long-term sustainable customer relationships. Consequently, we define perceived respect as the esteem or regard patrons give to a hotel. This notion of respect results from a patron's evaluation of being valued and treated with dignity by a hotel during value co-creation processes.

\section{Subjective wellbeing}

Transformative service research suggests subjective wellbeing (SWB) is an important predictor of positive actions and is an individual's cognitive and affective assessment of his or her life satisfaction, which can be measured as satisfaction with experiences over time (Diener, 2000). SWB complements traditional growth-oriented models of hospitality services by considering patrons' quality of life. For example, Kim, Jeon and Hyun (2012) found hedonic value and brand attitude have a positive impact on patron wellbeing, while Mody, Suess, \& Lehto (2017) found customer experience is related to wellbeing. Although hotel experiences can 
influence patrons' SWB, there are still questions to be addressed, such as the extent to which a patron's engagement in the value co-creation process affects their wellbeing.

\section{Antecedents to VCCBs}

Social exchange theory (Blau, 1964) suggests people respond differently to fair or unfair treatment. When patrons feel they have had a fair hotel encounter, they are likely to feel obliged to reciprocate by collaborating and engaging their resources with those of the hotel. However, when they feel they have received unfair treatment, they may adhere to negative reciprocity norms and withdraw from such behaviors. It is also possible that they will restrict their efforts to merely satisfy contractual obligations (such as through participation behaviors) (Yi \& Gong, 2008). Similarly, affect control theory (Chebat \& Slusarczyk, 2005) suggests patrons who are treated fairly will experience positive affect, which may lead to participation and VCCBs. Jaakkola and Alexander (2014) also found VCCB might be influenced by customers' perception of fairness. It seems when patrons feel they have been treated fairly they are more likely to engage in VCCBs, as they feel obliged to reciprocate in a manner valued by the hotel, suggesting:

H1: Perceived service fairness has a positive influence on VCCB.

The commitment-trust theory of relationship marketing (Morgan \& Hunt, 1994) suggests trust is central to relationships. Trust affects $\mathrm{VCCB}$, as patrons need to have confidence in a service provider before they engage in value co-creation processes. Patrons have to share valuable resources, and trust enables them to rule out undesirable outcomes from such processes. Trust reduces uncertainty, fear and risk, increases confidence, and enhances relationship commitment (Kim et al., 2009). It generates value by increasing relational benefits and reducing relationship uncertainty; while a lack of trust adversely affects beliefs about a provider, making 
people less likely to share resources, as is required for VCCB. Thus, trust is a prerequisite for people to engage in value co-creation. Trust in a hotel helps the formation of relationships that motivates people to co-operate and engage in in-role and extra-role behaviors, suggesting:

H2: Trust has a positive influence on VCCB.

Customer-company identification (CCID) is "the primary psychological substrate for the kind of deep, committed, and meaningful relationships that marketers are increasingly seeking to build with their customers" (Bhattacharya \& Sen, 2003, p. 76). Several theoretical considerations support the role of identity as a key motivation for customer participation in service interactions (Luu, Rowley, \& Dinh, 2018). From a social identity perspective, when customers identify with a service provider, they are more likely to engage in in-role behaviors, such as increasing the repurchase intention, being willing to pay premium, and making positive service evaluations (Fisher et al., 2010). CCID is one of the means to develop long-term relationships with customers and engender customer loyalty (Bagozzi et al. 2012). People who identify with a service provider also engage in extra-role behaviors (Ahearne, Bhattacharya, \& Gruen, 2005). Therefore, the consumer's state of belongingness with a service provider may be key in determining the participation of the customer in the value co-creation process, suggesting:

H3: Customer-company identification has a positive influence on VCCB.

\section{Perceived service fairness, trust, and CCID}

Scholars have indicated that how trust evolves between the customer and the service provider in the value co-creation process is of significance (Pera, Occhiocupo, \& Clarke, 2016). Seiders and Berry (1998, p. 9) suggested "fairness is a necessary condition for trust, and trust counterbalances the risk and uncertainty endemic to service exchanges. Just as perceived unfairness can destroy trust, perceptions of particularly fair treatment can have a positive 
influence on trust". Prior hospitality research identified trust as an important outcome of fairness. For example, Kwortnik and Han (2011) found distributive and interaction fairness influences trust, while Nikbin, Marimuthu, and Hyun (2016) found price, procedural, and interpersonal fairness is positively related to trust. These studies suggest fair treatment is pivotal to the development of trust. When patrons feel they are treated fairly, they feel confident and trust the hotel; whereas when they perceive a lack of fairness, they are less likely to rely on the hotel, suggesting:

$\mathbf{H}_{4}$ : Perceived service fairness has a positive influence on trust.

While CCID helps build relationship equity, there is little evidence as to how service fairness influences CCID. So et al. (2017) found people develop identification with a service provider when they encounter memorable experiences, suggesting CCID is determined by people's evaluation of service encounters. The relationship between service fairness and CCID can be drawn from the group engagement model (Blader \& Tyler, 2009), which suggests fairness affects people's social identity and behavior, as it provides cues as to whether people should invest their social identities in a group. Thus, when customers receive fair services, they develop favorable perceptions and identify with that service provider. Moreover, the level of identification is formed on the basis of customers' information and experience with the service provider (Ahearne et al., 2005). Thus, when patrons perceive fairness in hotel service encounters, they are more likely to identify with that hotel, suggesting:

H5: Fairness has a positive influence on customer-company identification.

\section{Consequences of VCCBs}

Building on SDL (Vargo \& Lusch, 2004), this study suggests a patron's respect for a hotel is influenced by their participation in the value co-creation process. When the service 
provider successfully facilitates value co-creation, customers may perceive greater respect or admiration toward the service provider for their competence and collaboration efforts. While there is little evidence of the relationship between value co-creation and perceived respect, some studies suggest VCCB is associated with respect for a service provider. For example, Grissemann and Stokburger-Sauer (2012) found satisfaction with co-creation performance contributes to a positive firm status; while Chen and Wang (2016) found customer participation in the value co-creation process helps in the realization of economic, enjoyment, and relational value. As value co-creation involves the collaboration between customers and providers, patrons are likely to evaluate a hotel's efforts in such processes positively by offering respect and recognition, suggesting:

H6: VCCB has a positive influence on respect for a hotel.

As VCCB includes citizenship behaviors such as helping other customers and providing feedback to the service provider, we propose that it has a positive impact on customer sense of wellbeing. This is because people are most happy when they socialize and have intimate relationship with others. Helping others is related to perceived happiness (Kasser \& Sheldon, 2002; Liu \& Aaker, 2008). Several studies have demonstrated that helping others makes people happy directly and indirectly through financial detachment (Cherrier \& Munoz, 2007). Given this, we propose that VCCB engenders and strengthens positive feelings among customers, contributing to their sense of wellbeing. Furthermore, the influence VCCB has on SWB can also be explained by the bottom-up spillover model (Andrews \& Withey, 1976), which suggests positive and negative feelings can spill over from concrete events to life domains, such as work, social life, or overall life. Thus, satisfaction with services received can spill over to people's feeling of wellbeing and satisfaction with life. Sirgy et al. (2011) found service experience plays 
an important role in customers' wellbeing, while Mathis et al. (2016) found satisfaction with the co-creation experience influences people's wellbeing. When patrons actively participate and cocreate value, their satisfaction will be improved, positively affecting their SWB, suggesting:

H7: VCCB has a positive influence on subjective wellbeing.

The study undertaken to examine these hypotheses, the results obtained, and their implications are discussed in subsequent sections.

\section{Methodology}

\section{Sample and procedure}

We collected data from hotel patrons who recently stayed at a 4-star or 5-star hotel. In essence, patrons of upmarket hotels are guests of hospitality services. According to the SDL (Vargo \& Lusch, 2008), in an interactional service process, value is co-created and determined by customers. Specifically, upmarket hotels excel at customization because they allocate more resources to the value co-creation process (Chathoth et al., 2013). Chathoth et al. (2013) argued that upmarket hotels often provide patrons with clear information about their resources regarding housekeeping, food, concierge services, and so forth; the patrons then choose the best available option that is closest to meeting his/her need(s). For instance, luxury hotel patrons are able to provide their inputs on what type of pillow (soft, medium, or hard) they prefer, according to which the hotel would provide the pillow to the patron's satisfaction (Chathoth et al., 2013). On the contrary, there are usually no other types of pillows for patrons at budget hotels to choose from even if they find the current offerings uncomfortable.

We tested the proposed research model in two developed countries (Australia and the US). These countries are chosen as they have similar cultural values (Hofstede, 2001). Using two countries with similar cultural backgrounds can provide a more convincing argument about 
VCCB's antecedents and consequences than conducting a study in a single country or in culturally different countries.

A commercial research company collected data by administering the questionnaire to panels in the two countries over a 3-day period in 2017. The company was selected because of its access to the populations of interest and the rigorous procedures to select representative samples. Participants, who were older than 18 years of age and stayed at a 4-star or a 5-star hotel (e.g., Ritz Carlton, Crowne Plaza, Four Seasons, Intercontinental, Belmont Hotel, Hyatt, Marriott) during the past six months, were asked to reflect on their most recent hotel experience when responding to the questionnaire. Each respondent provided the name of the four-star or five-star hotel in which they stayed most recently, and in subsequent questions, the hotel name appeared in the questionnaire.

\section{Measures}

This study adapted scales for respective constructs from the previous literature to fit the hotel context (see Appendix 1). The four fairness dimensions were measured using 17 items from Devlin, Roy, and Sekhon's (2014) scale. Kim et al.'s (2009) four-item scale was used to measure trust. CCID was measured through three items from Mael and Ashforth's (1992) scale. The eight VCCB dimensions were measured through 29 items from Yi and Gong's (2013) study. Subjective wellbeing was measured by three items from Su et al.'s (2016) scale. Finally, perceived respect was measured by three items developed for this study based on Hendrick and Hendrick's (2006) and Tyler and Blader's (2002) studies. Consistent with prior research, age, gender, the nature of the trip (business or leisure), and prior hotel experience were included as control variables. 


\section{Respondents' profiles}

The total usable sample size is 2098. In the Australian sample, 1323 completed responses were received, with $47 \%$ being male. Most were in the age group 36 to 50 years (36\%) and older than 50 years (33\%). More respondents were employed in the private sector (49\%) and had a Bachelor level qualification (42\%) or a high-school education (31\%). In the US sample, 775 completed responses were received with $44 \%$ being male. Most respondents were in the age group 26 to 35 years (38\%) and between 36 and 50 years (32\%). More were employed in the private sector (54\%) and had a high-school education (38\%) or a Bachelor level qualification (40\%). Chi-square tests did not show any significant differences in the profiles of the two samples, providing evidence of sample equivalence.

\section{Results}

We used partial least squares structural equation modeling (PLS-SEM) to test the proposed hypotheses and SmartPLS 3.0 program to estimate the model. A repeated-indicator approach (Becker, Klein, \& Wetzels, 2012) was used to construct the second-order perceived service fairness and third-order VCCB constructs, and a two-step approach was used to establish the reliability and validity of the measurement model. Convergent validity was assessed through the strength and significance of the factor loadings and average variance extracted (AVE) scores, while discriminant validity was assessed using the HTMT-ratio approach.

\section{Common method bias}

Since all responses were provided by the same respondent, the possibility of the common method bias was addressed using procedural and statistical methods suggested by Podsakoff, MacKenzie and Podsakoff (2012). Regarding the procedural methods, we assured respondents of the anonymity of their responses and that there were no right or wrong answer. We pre-tested the 
questionnaire to avoid vague questions and complex syntax. The questions were kept simple, specific, and concise. Regarding the statistical remedies, we used Harman's single factor test, which showed that no single factor accounted for more than $50 \%$ of the total variance (Australia: $24.55 \%$ variance explained by the $1^{\text {st }}$ factor; US: $25.52 \%$ variance explained by the $1^{\text {st }}$ factor). This suggests that common method bias is not a concern in the present study (Podsakoff et al., 2012).

Reflective constructs

One measurement item each was removed from the tolerance, information sharing, perceived respect, responsible behavior, and trust constructs, as their factor loadings were less than 0.70. As can be seen in Table 1, the internal consistencies for all of the constructs in the two samples exceed the recommended minimum value of 0.70. Similarly, all AVE scores exceed the minimum value of 0.50 in both datasets. Thus, consistency and convergent validity were established for all the reflective constructs.

[Insert Table 1 about here]

Discriminant validity was established through the HTMT-ratio approach. The threshold discriminant validity values for the HTMT ratio and confidence interval $(<0.90$ and 1.00 respectively) were met (Henseler, Ringle, \& Sarstedt, 2015). An examination of the crossloadings also found each item loaded highest on its underlying constructs (Table 2), supporting discriminant validity.

[Insert Table 2 about here]

\section{Formative constructs}

Perceived service fairness was modeled as a second-order formative construct and examined using Diamantopoulos and Winklhofer's (2001) guidelines. First, the correlations 
among the four dimensions vary from 0.76 to 0.81 , with an average of 0.78 across contexts. Although these correlations are high, perceived service fairness is still better represented by a formative model since, in the latter case, the correlations among the first-order dimensions would be extremely high (>0.90). Further, all four dimensions have significant paths in forming overall service fairness (distributive fairness: $\beta_{\mathrm{US}}=0.23, \mathrm{t}=48.75, \mathrm{p}<0.01, \beta_{\mathrm{AUS}}=0.24, \mathrm{t}=67.83, \mathrm{p}<$ 0.01; procedural fairness: $\beta_{\mathrm{US}}=0.31, \mathrm{t}=59.66, \mathrm{p}<0.01, \beta_{\mathrm{AUS}}=0.32, \mathrm{t}=84.84, \mathrm{p}<0.01$; interpersonal fairness: $\beta_{\mathrm{US}}=0.25, \mathrm{t}=54.41, \mathrm{p}<0.0, \beta_{\mathrm{AUS}}=0.25, \mathrm{t}=68.12, \mathrm{p}<0.01$; informational fairness: $\beta_{\mathrm{US}}=0.26, \mathrm{t}=41.41, \mathrm{p}<0.01, \beta_{\mathrm{AUS}}=0.26, \mathrm{t}=85.98, \mathrm{p}<0.01$ ). Procedural fairness is the most important dimension, followed by informational fairness. These results can be attributed to the study context, as clear processes and policies need to be communicated to patrons engaging in VCCBs.

Following Yi and Gong (2013), the VCCB construct was modeled as a third-order construct with two formative second-order constructs (citizenship behavior and participation behavior). Further, the eight first-order dimensions were modeled as behavioral manifestations of the second-order constructs. Figure 2 shows the results of the hierarchical factor structure of the VCCB construct for the two samples. The first-order, second-order, and third-order loadings are high and statistically significant, providing support for modeling the VCCB construct as a thirdorder factor.

\section{[Insert Figure 2 about here]}

\section{The structural model}

The predictive relevance of the model was confirmed using Stone-Geisser's $Q^{2}$ statistics, which were all well above 0.00 (Table 3). The structural model was evaluated based on the $\mathrm{R}^{2}$ 
values of the endogenous constructs and the size and significance of the path coefficients (Hair et al., 2012).

Variance explained is a key criterion for assessing PLS-SEM models (Hair et al., 2014). As shown in Table 3, the $\mathrm{R}^{2}$ values in both samples are greater than 0.10 (Falk \& Miller, 1992), except for CCID in the Australian sample $\left(\mathrm{R}^{2}=0.08\right)$. However, the average variance accounted for in the model's endogenous variables are 32\% and 37\% for the Australian and US samples respectively, which are greater than the 0.10 level suggested by Falk and Miller (1992). It seems the exogenous variables explain a substantial amount of the variance in the endogenous variables in both samples.

[Insert Table 3 about here]

Table 4 and Figure 3 show that all of the direct effect hypotheses are confirmed. A multiple-group analysis was used to examine whether there were differences between the two samples. Following an examination of the measurement invariance (Henseler, Ringle, \& Sarstedt, 2016), the structural invariance was tested. As can be seen in Table 4, there are no significant differences in the path coefficients across the samples, providing support for the empirical generalization of the relationships examined here. None of the control variables has a significant effect on perceived respect or wellbeing.

[Insert Table 4 about here]

[Insert Figure 3 about here]

\section{Post-hoc mediation analysis}

The model's indirect effects were tested using SmartPLS bootstrapping approach (with 5000 bootstrapping resamples). Trust (Australia: indirect effect $=0.15, \mathrm{p}<0.01, \mathrm{LCI}=0.12$, $\mathrm{UCI}=0.18$; US: indirect effect $=0.17, \mathrm{p}<0.01 \mathrm{LCI}=0.12, \mathrm{UCL}=0.23$ ) and CCID (Australia: 
indirect effect $=0.09, \mathrm{LCI}=0.06, \mathrm{UCI}=0.11$; US: indirect effect $=0.11, \mathrm{p}<0.01, \mathrm{LCI}=0.09$, $\mathrm{UCL}=0.15)$ mediates the relationship between perceived service fairness and VCCB. VCCB mediates the relationship between trust and perceived respect toward the hotel (Australia: indirect effect $=0.20, \mathrm{LCI}=0.15, \mathrm{UCI}=0.24$; $\mathrm{US}$ : indirect effect $=0.21, \mathrm{p}<0.01, \mathrm{LCI}=0.15$, $\mathrm{UCL}=0.27$ ), as well as that between trust and subjective wellbeing (Australia: indirect effect $=$ $0.10, \mathrm{LCI}=0.07, \mathrm{UCI}=0.13 ; \mathrm{US}$ : indirect effect $=0.12, \mathrm{LCI}=0.08, \mathrm{UCL}=0.18) . \mathrm{VCCB}$ mediates the relationship between CCID and perceived respect (Australia: indirect effect $=0.21$, $\mathrm{LCI}=0.16, \mathrm{UCI}=0.25$; $\mathrm{US}$ : indirect effect $=0.25, \mathrm{LCI}=0.20, \mathrm{UCL}=0.30$ ), as well as that between CCID and subjective wellbeing (Australia: indirect effect $=0.10, \mathrm{LCI}=0.08, \mathrm{UCI}=$ 0.13; US: indirect effect $=0.16, \mathrm{LCI}=0.13, \mathrm{UCL}=0.20)$.

\section{Discussion and implications}

This study, which examines the antecedents and consequences of VCCB in a hospitality setting, has a number of valuable findings. Overall, the findings support the model and suggest that hotel patrons engage in VCCBs based on an evaluation of the service encounter (service fairness) and the provider (trust and CCID), which, in turn, influences their wellbeing and respect for the provider.

These findings have important theoretical implications. First, empirical support was found for a VCCB model in a hotel setting. While the hospitality literature has made recent efforts to examine value co-creation (Chathoth et al., 2016; Im \& Qu, 2017), this study extends our understanding by testing a parsimonious, yet robust model of the antecedents and consequences of VCCB. The study shows the roles service fairness, trust, and identification play in influencing hotel patrons to engage in VCCBs and the effects these behaviors have on their wellbeing and respect for the service provider. More importantly, the study departs from prior 
studies that are predominantly qualitative and conceptual (e.g., Cabiddu, Lui, \& Piccoli, 2013; Campos et al., 2015) by using a quantitative approach. This is an important contribution, as it fills a need for empirical studies in the value co-creation domain (Morosan \& DeFranco, 2016). Further, the study contributes to the development of a generalizable VCCB model by demonstrating its robustness across two countries.

Second, the study addresses the lack of research into the antecedents of VCCB (Ranjan \& Read, 2016) by focusing on the relationships between service encounters (perceived service fairness), service provider related factors (trust, COID), and VCCB. Since the relationships between these constructs have not been fully examined previously, this study provides initial evidence linking service-related and provider-related characteristics to customer VCCB. Most notably, the study validates the direct and indirect effects that perceived fairness, trust, and CCID have on VCCB. These findings recognize the role the service environment plays in shaping VCCB. Third, the study shows that perceived fairness has the greatest effect on VCCB, suggesting that people are more willing to engage in VCCBs if they perceive fairness in a service encounter. This is important, as it extends our understanding of the impact service fairness has on customer participation and citizenship behaviors.

Fourth, the finding that VCCB has an impact on SWB supports Mathis et al.'s (2016) suggestion that value co-creation may bring life satisfaction beyond its economic benefits. These findings suggest that co-creation is not only about people becoming value co-creators, but also about co-creation improving people's wellbeing. Thus, these findings contribute to a growing body of research in transformative service research and value co-creation. Finally, the results suggest that VCCB significantly influences patron respect for a service provider, which is likely to have long-term implications for their loyalty to the hotel they visit. 


\section{Managerial Implications}

This study has some important practical implications for the hotel industry. First, by developing an integrated model of antecedents and consequences of VCCB, the present study provides hotel managers with an in-depth understanding of the mechanism of value co-creation. Specifically, this study offers valuable insights in developing and implementing service strategies to encourage hotel patrons' VCCBs. For example, hotels can use mobile apps to actively engage patrons in co-creating personalized experiences in key hotel service processes such as room reservation, check-in/out, and service feedback.

Second, hotels can segment patrons based on their VCCBs and identify patrons who are active in VCCBs. By rewarding these patrons, hotels can further engage them in the value cocreation process. Furthermore, hotels can design loyalty programs that focus on creating personalized experiences. For example, they can provide special events or offers for patrons who are active in value co-creation, thereby strengthening the interaction and relationship with them. Hyatt rewards its members with personalized expedition cruises and adventure travel experiences to engage them and enhance their wellbeing (Ben, 2019).

Third, the study findings show that VCCB leads to the patron's wellbeing and respect toward the hotel. Therefore, hotels should create an environment that is favorable for value cocreation and offer improved service benefits that could motivate patrons to engage in VCCBs. For example, hotels can create online communities for members to interact with each other and share their experiences. Hotels should also extend their communication beyond the standard media like e-mails. More specifically, they could create a more active dialogue through digital apps or loyalty programs that can tailor the communication for each patron. Furthermore, as value is created through the customer's collaboration with the service provider, hotels should 
invest in developing patrons' competencies in the co-creation process through providing necessary information, resources, and assistance. For example, Marriott members would receive Room Ready Alerts and use their smartphones as their room key on Marriott's mobile apps (Wolf, 2018).

Fourth, a patron's perceived fairness is crucial in promoting their VCCBs. It is thus in a hotel operator's best interest to offer specific training programs, establish staff reward policies, and provide detailed job descriptions to motivate and help staff deliver exceptional service from an interactional, informational, and procedural fairness perspective. Hotels should also design appropriate service processes to make the service delivery frictionless and deal with complaints as soon as they arise. Hotels can adopt guest-facing technologies that enable staff to access upto-date information on customer complaints and take appropriate actions quickly. An effective service recovery approach is to create a guest profile based on their booking information, past stay history, and requests they made. This information should provide hotels with an edge for engaging patrons in the value co-creation process and swiftly dealing with complaints. For example, One\&Only Resorts builds the incoming guest profile by looking up their past stay history and social media activities (Lindberg, 2013). In this sense, hotels should develop information systems and employ digital analytics to gather and analyze data about the services and amenities patrons want. This information would help them offer fair service encounters, assist in the co-creation of experiences, and provide the information needed for staff to deal with patron complaints.

Finally, the study findings indicate the crucial role of CCID and trust in affecting VCCB. It is crucial for hotel managers to understand these links and create an environment that makes patrons feel identified with the hotel and confident in its services. As prior studies suggest that 
customers can develop strong identification with a company when they are involved in pleasureoriented loyalty programs (Kang, Alejandro, \& Groza, 2015), hotels can use loyalty programs that communicate their core values and offer hedonic benefits (e.g., spa treatment, live shows and events, cruise experiences). To enhance trust, hotels should ensure they reduce anxiety and uncertainty for patrons by being honest, consistent, and reliable in marketing communications and service encounters. Considering that social media is constantly transforming ways customers connect with each other and with the companies, hotel operators may build social media-based brand communities and actively engage in direct interactions with customers on social media platforms.

\section{Limitations and future research directions}

Despite the study's contributions, there are limitations that offer opportunities for future research. This study used data collected from patrons in the US and Australia. Examining VCCB in other countries would increase external validity and suggest whether cultural differences would influence the relationships in the model. Future research might also examine more complex models to obtain a deeper understanding of the creation and assessment of value cocreation. Further, we examined VCCB in four-star and five-star hotels. Future research might examine VCCB in other hospitality and tourism settings, such as in restaurants, B\&B properties, adventure tourism, eco-tourism, and heritage tourism settings. The present study relied on crosssectional data collected from respondents who had stayed in hotels. Future studies should consider utilizing field observation or longitudinal designs to examine the causal relationships proposed in the present study.

\section{Appendix 1 (Measurement items)}




\section{Perceived service fairness \\ Distributive fairness}

DF1. Hotel employees have fully met my needs

DF2. Hotel employees served all customers equally without any bias

DF3. The hotel provided me with what I asked

DF4. The price of the hotel was reasonable for the services I received

Procedural fairness

PF1. I received service in a very timely manner

PF2. The service procedures of the hotel were reasonable

PF3. Hotel employees provided me with the information that was clear and understandable

PF4. Hotel employees seemed very knowledgeable about any of my questions or concerns

PF5. Hotel employees treated me flexibly according to my needs

Interpersonal fairness

IPF1. Hotel employees were courteous to me

IPF2. Hotel employees' communication with me was appropriate

IPF3. Hotel employees showed real interest in trying to be fair

IPF4. Hotel employees showed a concern

Informational fairness

INF1. The hotel provides timely and specific information

INF2. The hotel makes sure I understand the information it provides

INF3. Hotel employees showed interest to answer my questions

INF4. Hotel employees provide thorough explanations

Trust

TR1. This hotel can be trusted at all times

TR2. This hotel has a high level of integrity

TR3. This hotel made every effort to fulfill the promises it made*

TR4. Overall, this hotel is reliable

\section{Customer-company identification}

CCID1. I am very interested in what others think about the hotel

CCID2. This hotel's success is my success

CCID3. When someone praises this hotel, it feels like a personal compliment

Value co-creation behavior

Information seeking

IS1. I have asked others for information on what this hotel offers

IS2. I have searched for information on where this hotel is located

IS3. I have paid attention to how others behave to use this hotel and its services well

Information sharing

IF1. I clearly explained what I wanted the hotel employees to do

IF2. I gave the hotel employees proper information

IF3. I provided necessary information so that the hotel employees could perform their duties

IF4. I answered all the hotel employees' service-related questions*

Personal interaction

PI1. I was friendly to the hotel employees

PI2. I was kind to the hotel employees

PI3. I was polite to the hotel employees

PI4. I was courteous to the hotel employees 
PI5. I didn't act rudely to the hotel employees

Responsible behavior

RB1. I performed all the tasks that are required

RB2. I adequately completed all the expected behaviors

RB3. I fulfilled responsibilities to the hotel

RB4. I followed the hotel's rules or regulations*

Advocacy

AD1. I said positive things about the hotel and the employees to others

AD2. I recommended hotel and the employees to others

AD3. I encouraged friends and relatives to use the hotel

Helping

HP1. I assist other customers if they need my help

HP2. I help other customers if they seem to have problems

HP3. I teach other customers to use the service correctly

HP4. I give advice to other customers

Tolerance

TL1. If service is not delivered as expected, I would be willing to put up with the hotel*

TL2. If the hotel employee makes a mistake during service delivery, I would be willing to be patient

TL3. If I have to wait longer than I normally expected to receive the service, I would be willing to adapt

Feedback

FD1. If I had a useful idea on how to improve service, I let the hotel employee know

FD2. When I received good service from the hotel employee, I comment about it

FD3. When I experienced a problem, I let the employee know about it

Subjective wellbeing

SWB1. In general, I consider myself a very happy person

SWB2. Compared to most of my peers, I consider myself more happy

SWB3. I am generally very happy and enjoy life

Perceived respect

PR1. I respect this hotel

PR2. I am willing to continue my relationship with the hotel

PR3. This hotel has a good impression on me

PR4. I honor this hotel*

Note: $*$ denote items dropped from final analysis

References

Adams, J. S. 1963. Towards an understanding of inequity. Journal of Abnormal and Social Psychology 67(5), 422-436. 
Ahearne, M., Bhattacharya, C. B., and Gruen, T. 2005. Antecedents and consequences of customer-company identification: Expanding the role of relationship marketing. Journal of Applied Psychology 90(3), 574-585.

Ahn, J., Lee, C. K., Back, K. J., and Schmitt, A. 2019. Brand experiential value for creating integrated resort customers' co-creation behavior. International Journal of Hospitality Management, 81, 104-112.

Andrews, F. M., and Withey, S. B. 1976. Social indicators of wellbeing: Americans' perceptions of life quality. New York: Plenum Press.

Bagozzi, R. P., Bergami,M., Marzocchi, G. L., and Morandin, G. 2012. Customerorganization relationships: Development and test of a theory of extended identities. Journal of Applied Psychology, 97(1), 63-76.

Becker, J. M., Klein, K., and Wetzels, M. 2012. Hierarchical latent variable models in PLS-SEM: Guidelines for using reflective-formative type models. Long Range Planning 45(5-6), 359-394.

Ben. 2019. Now Live: Hyatt \& Lindblad Expeditions partnership. Accessed from https://onemileatatime.com/hyatt-lindblad-expeditions/.

Beugre, C. D., and Baron, R. A. 2001. Perceptions of systemic justice: The effects of distributive, procedural, and interactional justice. Journal of Applied Social Psychology 31(2), 324-339.

Bhattacharya, C. B., and Sen, S. 2003. Consumer-company identification: A framework for understanding consumers' relationships with companies. Journal of Marketing 67(2), 76-88. 
Blader, S. L., and Tyler, T. R. 2009. Testing and extending the group engagement model: Linkages between social identity, procedural justice, economic outcomes, and extrarole behavior. Journal of Applied Psychology 94(2), 445-464.

Blau, P.M. 1964. Exchange and Power in Social Life. Transaction Publishers, London. Bova, T. 2018. How Marriott is changing the hotel game with personalization. Technonomy. Accessed from https://techonomy.com/2018/08/marriott-changing-hotel-gamepersonalization/.

Cabiddu, F., Lui, T. W., and Piccoli, G. 2013. Managing value co-creation in the tourism industry. Annals of Tourism Research 42, 86-107.

Camilleri, J. and Neuhofer, B. 2017. Value co-creation and co-destruction in the Airbnb sharing economy. International Journal of Contemporary Hospitality Management 29(9), 23222340.

Campos, A. C., Mendes, J., Valle, P. O. D., and Scott, N. 2015. Co-creation of tourist experiences: A literature review._Current Issues in Tourism 21(4), 369-400.

Chathoth, P., Altinay, L., Harrington, R. J., Okumus, F., and Chan, E. S. 2013. Coproduction versus co-creation: A process based continuum in the hotel service context. International Journal of Hospitality Management 32, 11-20.

Chathoth, P. K., Ungson, G. R., Harrington, R. J., and Chan, E. S. 2016. Co-creation and higher order customer engagement in hospitality and tourism services: A critical review. International Journal of Contemporary Hospitality Management, 28(2), 222-245.

Chebat, J. C., and Slusarczyk, W. 2005. How emotions mediate the effects of perceived justice on loyalty in service recovery situations: An empirical study. Journal of Business Research 58(5), 664-673. 
Chen, S. C., Raab, C., and Tanford, S. 2015. Antecedents of mandatory customer participation in service encounters: An empirical study. International Journal of Hospitality Management, 46, 65-75.

Chen, C. F., and Wang, J. P. 2016. Customer participation, value co-creation and customer loyalty: A case of airline online check-in system. Computers in Human Behavior 62, $346-352$.

Cherrier, H., and Munoz, C. L. 2007. A Reflection on Consumers' Happiness: The Relevance of Care for Others, Spiritual Reflection, and Financial Detachment. Journal of Research for Consumers, (12), 1-19.

Chiu, C. M., Huang, H. Y., and Yen, C. H. 2010. Antecedents of trust in online auctions. Electronic Commerce Research and Applications 9(2), 148-159.

Choi, S., and Kim, S. 2013. Effects of a reward program on inducing desirable customer behaviors: The role of purchase purpose, reward type and reward redemption timing. International Journal of Hospitality Management, 32, 237-244.

Chou, E. Y., Lin, C. Y., and Huang, H. C. 2016. Fairness and devotion go far: Integrating online justice and value co-creation in virtual communities. International Journal of Information Management 36(1), 60-72.

Devlin, J. F., Roy, S. K., and Sekhon, H. 2014. Perceptions of fair treatment in financial services: Development, validation and application of a fairness measurement scale. European Journal of Marketing 487(7-8), 1315-1332.

DeWitt, T., Nguyen, D. T., and Marshall, R. 2008. Exploring customer loyalty following service recovery: The mediating effects of trust and emotions. Journal of Service Research 10(3), $269-281$. 
Diamantopoulos, A., and Winklhofer, H. M. 2001. Index construction with formative indicators: An alternative to scale development. Journal of Marketing Research 38(2), 269-277.

Diener, E. 2000. Subjective wellbeing: The science of happiness and a proposal for a national index. American Psychologist 55(1), 34-43.

Falk, R. F., and Miller, N. B. 1992. A primer for soft modeling. University of Akron Press, Akron.

Fisher, R., McPhail, R., and Menghetti, G. 2010. Linking employee attitudes and behaviors with business performance: A comparative analysis of hotels in Mexico and China. International Journal of Hospitality Management 29(3), 397-404.

Golubovskaya, M., Robinson, R. N., \& Solnet, D. 2017. The meaning of hospitality: Do employees understand? International Journal of Contemporary Hospitality Management 29(5), 1282-1304.

Grönroos, C. 2011. Value co-creation in service logic: A critical analysis. Marketing Theory 11(3), 279-301.

Grissemann, U. S., and Stokburger-Sauer, N. E. 2012. Customer co-creation of travel services: The role of company support and customer satisfaction with the co-creation performance. Tourism Management 33(6), 1483-1492.

Hair, J. F., Sarstedt, M., Ringle, C. M., and Mena, J. A. 2012. An assessment of the use of partial least squares structural equation modeling in marketing research. Journal of the Academy of Marketing Science 40(3), 414-433.

Hair, J.F., Hult, G.T.M., Ringle, C.M. and Sarstedt, M. 2014, A Primer on Partial Least Squares, Structural Equation Modeling (PLS-SEM), Thousand Oaks: Sage. 
Harkison, T., 2018. The use of co-creation within the luxury accommodation experience: Myth or reality? International Journal of Hospitality Management, 71, 11-18.

Hendrick, S. S. and Hendrick, C. 2006. Measuring respect in close relationships. Journal of Social and Personal Relationships 23(6), 881-899.

Henseler, J., Ringle, C. M., and Sarstedt, M. 2015. A new criterion for assessing discriminant validity in variance-based structural equation modeling. Journal of the Academy of Marketing Science, 43(1), 115-135.

Henseler, J., Ringle, C. M., and Sarstedt, M. 2016. Testing measurement invariance of composites using partial least squares. International Marketing Review 33(3), 405-431.

Hofstede, G. 2001. Culture's Consequences: Comparing Values, Behaviors, Institutions and Organizations across Nations. Thousand Oaks: Sage.

Im, J., and Qu, H. 2017. Drivers and resources of customer co-creation: A scenario-based case in the restaurant industry. International Journal of Hospitality Management 64, 31-40.

Jaakkola, E., and Alexander, M. 2014. The role of customer engagement behavior in value co-creation: A service system perspective. Journal of Service Research 17(3), 247-261.

Jin, N., Lee, S., and Huffman, L. 2012. Impact of restaurant experience on brand image and customer loyalty: Moderating role of dining motivation. Journal of Travel \& Tourism Marketing, 29(6), 532-551.

Kang, J., Alejandro, T. B., and Groza, M. D. 2015. Customer-company identification and the effectiveness of loyalty programs. Journal of Business Research, 68(2), 464-471.

Kasser, T., and Sheldon, K. M. 2002. What makes for a merry Christmas? Journal of Happiness Studies, 3(4), 313-329. 
Kim, I., Mi Jeon, S., and Sean Hyun, S. 2012. Chain restaurant patrons' wellbeing perception and dining intentions: The moderating role of involvement. International Journal of Contemporary Hospitality Management 24(3), 402-429.

Kim, T. T., Kim, W. G., and Kim, H. B. 2009. The effects of perceived justice on recovery satisfaction, trust, word-of-mouth, and revisit intention in upscale hotels. Tourism Management 30(1), 51-62.

Kontzer, T. 2016. It's all about the customer at Hilton. Baseline. Accessed from http://www.baselinemag.com/crm/its-all-about-the-customer-at-hilton-2.html.

Kwortnik Jr, R. J., and Han, X. 2011. The influence of guest perceptions of service fairness on lodging loyalty in China. Cornell Hospitality Quarterly, 52(3): 321-332.

Laud, G., and Karpen, I. O. 2017. Value co-creation behaviour-Role of embeddedness and outcome considerations. Journal of Service Theory and Practice, 27(4), 778-807.

Lee, Y. H., Hsiao, C., and Chen, Y. C. 2017. Linking positive psychological capital with customer value co-creation. International Journal of Contemporary Hospitality Management 29(4), 1235-1255.

Lindberg, J.S. 2013. What your hotel knows about you. Travel+Leisure. Accessed from https://www.travelandleisure.com/articles/what-your-hotel-knows-about-you.

Liu, W., and Aaker, J. 2008. The happiness of giving: The time-ask effect. Journal of Consumer Research, 35(3), 543-557.

Liu, J. S., and Tsaur, S. H. 2014. We are in the same boat: Tourist citizenship behaviors. Tourism Management 42, 88-100. 
Luu, T. T., Rowley, C., and Dinh, K. C. 2018. Enhancing the effect of frontline public employees' individual ambidexterity on customer value co-creation. Journal of Business \& Industrial Marketing, 33(4), 506-522.

Mael, F., and Ashforth, B. E. 1992. Alumni and their alma mater: A partial test of the reformulated model of organizational identification. Journal of Organizational Behavior 13(2), 103-123.

Mathis, E. F., Kim, H. L., Uysal, M., Sirgy, J. M., and Prebensen, N. K. 2016. The effect of co-creation experience on outcome variable. Annals of Tourism Research 57, 62-75.

McColl-Kennedy, J. R., Vargo, S. L., Dagger, T. S., Sweeney, J. C., and Kasteren, Y. V. 2012. Health care customer value cocreation practice styles. Journal of Service Research 15(4), 370-389.

Mody, M. A., Suess, C., and Lehto, X. 2017. The accommodation experiencescape: A comparative assessment of hotels and Airbnb. International Journal of Contemporary Hospitality Management 29(9), 2377-2404.

Morgan, B. 2019. 50 stats that prove the value of customer experience. Forbes. Accessed from https://www.forbes.com/sites/blakemorgan/2019/09/24/50-stats-that-prove-the-value-ofcustomer-experience/\#2a836a364ef2.

Morgan, R. M., and Hunt, S. D. 1994. The commitment-trust theory of relationship marketing. The Journal of Marketing 58(3), 20-38.

Morosan, C., and DeFranco, A. 2016. It's about time: Revisiting UTAUT2 to examine consumers' intentions to use NFC mobile payments in hotels. International Journal of Hospitality Management 53, 17-29. 
Namkung, Y., and Jang, S. C. 2010. Effects of perceived service fairness on emotions, and behavioral intentions in restaurants. European Journal of Marketing 44(9-10), 1233-1259.

Navarro, S., Llinares, C., and Garzon, D. 2016. Exploring the relationship between cocreation and satisfaction using QCA. Journal of Business Research 69(4), 1336-1339.

Nikbin, D., Marimuthu, M., and Hyun, S. S. 2016. Influence of perceived service fairness on relationship quality and switching intention: An empirical study of restaurant experiences. Current Issues in Tourism 19(10), 1005-1026.

Payne, A. F., Storbacka, K., and Frow. P. 2008. Managing the co-creation of value. Journal of the Academy of Marketing Science 36(1), 83-96.

Pera, R., Occhiocupo, N., and Clarke, J. (2016). Motives and resources for value cocreation in a multi-stakeholder ecosystem: A managerial perspective. Journal of Business Research, 69(10), 4033-4041.

Podsakoff, P. M., MacKenzie, S.B., and Podsakoff. N.P. 2012. Sources of method bias in social science research and recommendations on how to control it. Annual Review of Psychology 63, 539-569.

PWC. 2018. Experience is everything: Here's how to get it right. Accessed from https://www.pwc.de/de/consulting/pwc-consumer-intelligence-series-customer-experience.pdf.

Ranjan, K. R., and Read, S. 2016. Value co-creation: Concept and measurement. Journal of the Academy of Marketing Science 44(3), 290-315.

Seiders, K., and Berry, L. L. 1998. Service fairness: What it is and why it matters. Academy of Management Executive 12(2), 8-20. 
Sharma, S., Conduit, J., and Rao Hill, S. 2017. Hedonic and eudaimonic wellbeing outcomes from co-creation roles: a study of vulnerable customers. Journal of Services Marketing, 31(4/5), 397-411.

Shulga, L. V., Busser, J. A., and Kim, H. 2018. Generational Profiles in Value CoCreation Interactions. Journal of Hospitality Marketing \& Management 27(2), 196-217.

Sirgy, M. J., Kruger, P. S., Lee, D. J., and Yu, G. B. 2011. How does a travel trip affect tourists' life satisfaction? Journal of Travel Research 50(3), 261-275.

So, K. K. F., King, C., Sparks, B. A., and Wang, Y. 2013. The influence of customer brand identification on hotel brand evaluation and loyalty development. International Journal of Hospitality Management, 34, 31-41.

So, K. K. F., King, C., Hudson, S., and Meng, F. 2017. The missing link in building customer brand identification: The role of brand attractiveness. Tourism Management 59, 640651.

Su, L., Swanson, S. R., and Chen, X. 2016. The effects of perceived service quality on repurchase intentions and subjective wellbeing of Chinese tourists: The mediating role of relationship quality. Tourism Management 52, 82-95.

Swanson, S. R., and Hsu, M. K. 2009. Critical incidents in tourism: Failure, recovery, customer switching, and word-of-mouth behaviors. Journal of Travel and Tourism Marketing 26(2), 180-194.

Taheri, B., Coelho, F. J., Sousa, C. M., and Evanschitzky, H. 2017. Mood regulation, customer participation, and customer value creation in hospitality services. International Journal of Contemporary Hospitality Management 29(12), 3063-3081. 
Törnblom, K. Y., and Vermunt, R. 1999. An integrative perspective on social justice: Distributive and procedural fairness evaluations of positive and negative outcome allocations. Social Justice Research 12(1), 39-64.

Tyler, T. R., and Blader, S. L. 2002. Autonomous vs. comparative status: Must we be better than others to feel good about ourselves? Organizational Behavior and Human Decision Processes 89(1), 813-838.

Vargo, S. L., and Lusch, R. F. 2004. Evolving to a new dominant logic for marketing. Journal of Marketing 68(1), 1-17.

Vargo, S. L., \& Lusch, R. F. 2008. Service-dominant logic: continuing the evolution. Journal of the Academy of Marketing Science, 36(1), 1-10.

Wetzels, M., Odekerken-Schröder, G., \& Van Oppen, C. 2009. Using PLS path modeling for assessing hierarchical construct models: Guidelines and empirical illustration. MIS Quarterly 33(1), 177-195.

Wirtz, J., and Lwin, M. O. 2009. Regulatory focus theory, trust, and privacy concern. Journal of Service Research, 12(2), 190-207.

Wolf. 2018. Marriott international unveils unified loyalty program with one set of benefits. Accessed from https://news.marriott.com/news/2018/04/16/marriott-internationalunveils-unified-loyalty-programs-with-one-set-of-benefits.

Xie, L. S., Peng, J. M., and Huan, T. C. 2014. Crafting and testing a central precept in service-dominant logic: Hotel employees' brand-citizenship behavior and customers' brand trust. International Journal of Hospitality Management 42, 1-8. 
Yi, Y., and Gong, T. 2008. The effects of customer justice perception and affect on customer citizenship behavior and customer dysfunctional behavior. Industrial Marketing Management 37(7), 767-783.

Yi, Y., and Gong, T. 2013. Customer value co-creation behavior: Scale development and validation. Journal of Business Research 66(9), 1279-1284.

Yoon, S., and Lee, E. M. 2019. Social and psychological determinants of value cocreation behavior for South Korean firms: A consumer-centric perspective. Asia Pacific Journal of Marketing and Logistics, 31(1), 14-36. 


\section{Figures}

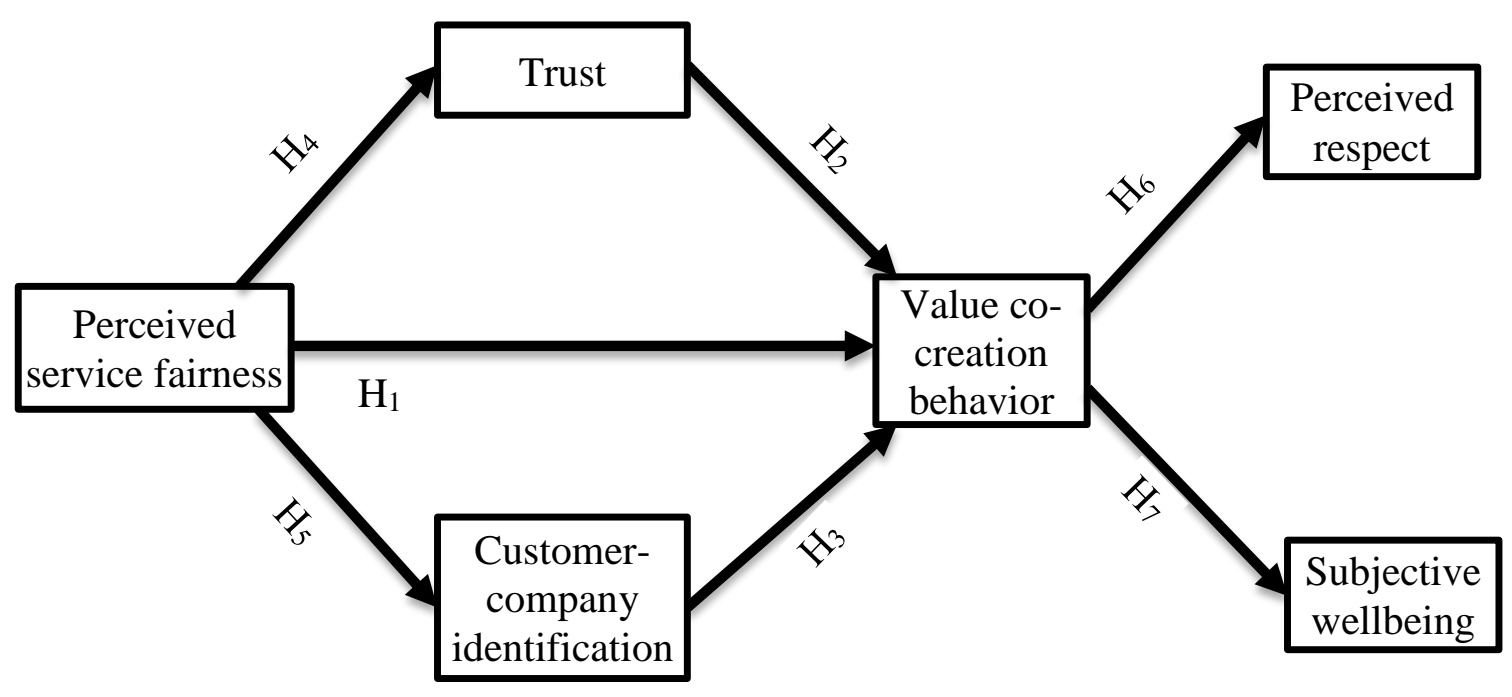

Figure 1. Conceptual framework of the study 


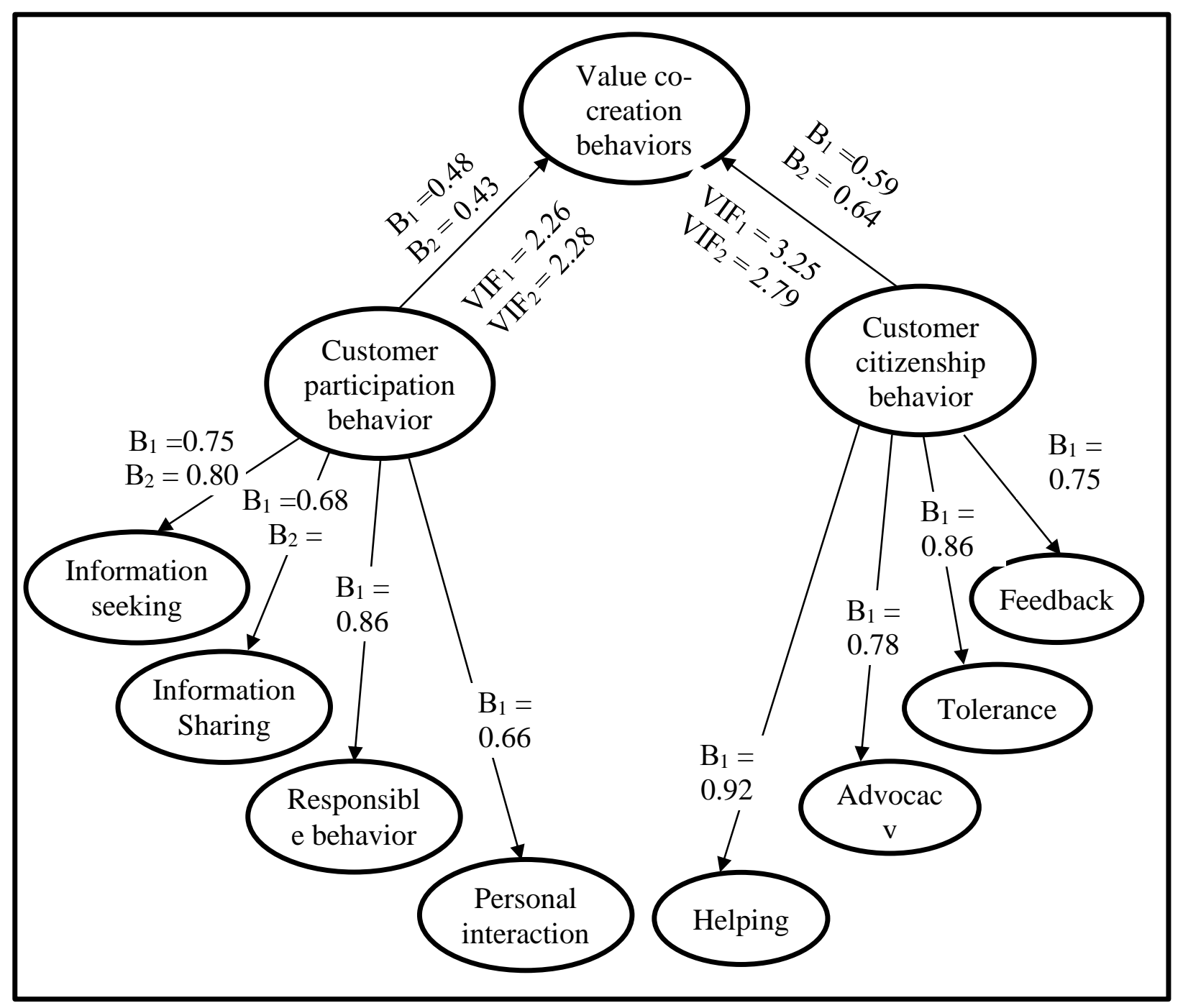

Figure 2. Third-order value co-creation behavior conceptualization

Note: $\mathrm{B}_{1}$ - factor loading in the US sample, $\mathrm{B}_{2}$ - factor loading in Australia sample, $\mathrm{VIF}_{1}$ variance inflation factor in the US sample, $\mathrm{VIF}_{2}$ - variance inflation factor in Australia sample. All factor loadings are significant at $\mathrm{p}<0.05$. 


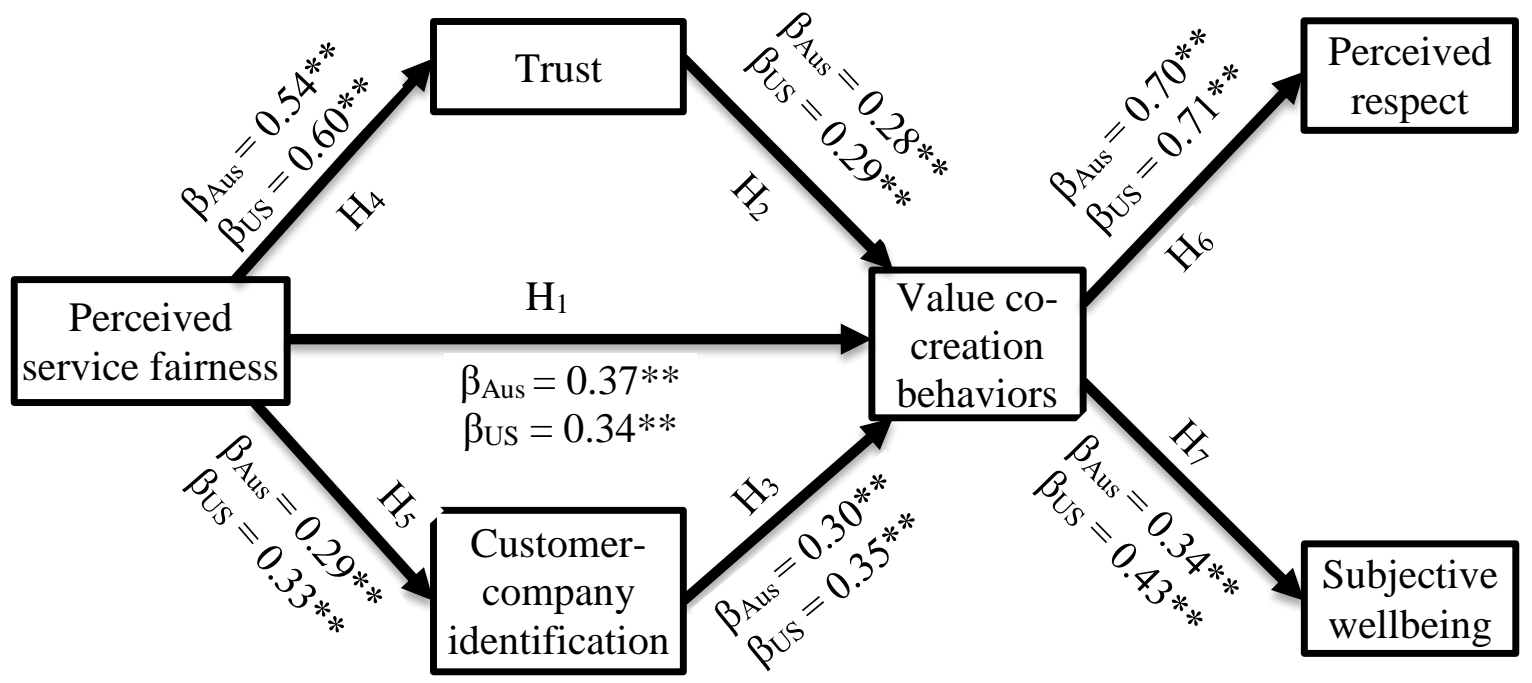

Figure 3. Structural model results for Australia and US samples 


\section{Tables}

\section{Table 1. Internal consistency of reflective constructs across contexts}

\begin{tabular}{lcc}
\hline \multicolumn{1}{c}{ Latent variables } & $\begin{array}{c}\text { Australia sample } \\
(n=1323)\end{array}$ & $\begin{array}{c}\text { US sample } \\
(n=775)\end{array}$ \\
\hline & $\alpha / \mathrm{CR} / \mathrm{AVE}$ & $\alpha / \mathrm{CR} / \mathrm{AVE}$ \\
\hline Distributive fairness & $0.87 / 0.91 / 0.72$ & $0.84 / 0.90 / 0.69$ \\
Procedural fairness & $0.93 / 0.95 / 0.78$ & $0.92 / 0.94 / 0.75$ \\
Interpersonal fairness & $0.95 / 0.96 / 0.86$ & $0.93 / 0.95 / 0.83$ \\
Informational fairness & $0.94 / 0.96 / 0.85$ & $0.92 / 0.95 / 0.82$ \\
Trust & $0.78 / 0.95 / 0.70$ & $0.75 / 0.86 / 0.66$ \\
Customer-company identification & $0.87 / 0.92 / 0.79$ & $0.89 / 0.93 / 0.82$ \\
Information seeking & $0.91 / 0.93 / 0.85$ & $0.91 / 0.93 / 0.84$ \\
Information sharing & $0.97 / 0.98 / 0.94$ & $0.96 / 0.97 / 0.93$ \\
Responsible behavior & $0.82 / 0.89 / 0.74$ & $0.81 / 0.88 / 0.72$ \\
Personal interaction & $0.88 / 0.91 / 0.68$ & $0.90 / 0.92 / 0.71$ \\
Feedback & $0.89 / 0.93 / 0.82$ & $0.86 / 0.91 / 0.78$ \\
Advocacy & $0.95 / 0.97 / 0.90$ & $0.93 / 0.95 / 0.87$ \\
Helping & $0.92 / 0.94 / 0.80$ & $0.90 / 0.93 / 0.77$ \\
Tolerance & $0.90 / 0.95 / 0.91$ & $0.89 / 0.95 / 0.90$ \\
Subjective wellbeing & $0.89 / 0.93 / 0.81$ & $0.87 / 0.92 / 0.79$ \\
Perceived respect & $0.80 / 0.87 / 0.70$ & $0.81 / 0.87 / 0.70$ \\
\hline
\end{tabular}

Note: $\alpha=$ Cronbach's alpha, $\mathrm{CR}=$ composite reliability, $\mathrm{AVE}=$ Average variance extracted. 


\begin{tabular}{|c|c|c|c|c|}
\hline \multicolumn{5}{|c|}{ Table 2. Factor loadings of constructs across contexts } \\
\hline & \multicolumn{2}{|c|}{ Australia sample $(n=1323)$} & \multicolumn{2}{|c|}{ US sample $(n=775)$} \\
\hline & Loading & $\mathrm{t}$-value & Loading & t-value \\
\hline \multicolumn{5}{|c|}{ Distributive fairness } \\
\hline DF1 & 0.90 & 144.04 & 0.90 & 98.19 \\
\hline DF2 & 0.84 & 67.13 & 0.84 & 49.47 \\
\hline DF3 & 0.75 & 38.64 & 0.70 & 23.46 \\
\hline DF4 & 0.90 & 24.07 & 0.87 & 66.08 \\
\hline \multicolumn{5}{|c|}{ Procedural fairness } \\
\hline PF1 & 0.88 & 75.78 & 0.87 & 67.39 \\
\hline PF2 & 0.90 & 99.07 & 0.89 & 72.82 \\
\hline PF3 & 0.92 & 162.52 & 0.90 & 78.44 \\
\hline PF4 & 0.89 & 107.93 & 0.88 & 58.97 \\
\hline PF5 & 0.81 & 42.60 & 0.79 & 30.62 \\
\hline \multicolumn{5}{|c|}{ Interpersonal fairness } \\
\hline IPF1 & 0.93 & 104.35 & 0.90 & 59.49 \\
\hline IPF2 & 0.93 & 115.82 & 0.93 & 122.69 \\
\hline IPF3 & 0.91 & 109.28 & 0.89 & 63.46 \\
\hline IPF4 & 0.94 & 67.42 & 0.93 & 98.95 \\
\hline \multicolumn{5}{|c|}{ Informational fairness } \\
\hline INF1 & 0.93 & 154.43 & 0.91 & 85.82 \\
\hline INF2 & 0.94 & 192.55 & 0.90 & 70.09 \\
\hline INF3 & 0.91 & 125.42 & 0.91 & 90.58 \\
\hline INF4 & 0.90 & 95.81 & 0.88 & 64.98 \\
\hline \multicolumn{5}{|l|}{ Trust } \\
\hline TRU1 & 0.76 & 61.37 & 0.81 & 31.93 \\
\hline TRU2 & 0.83 & 66.24 & 0.84 & 46.37 \\
\hline TRU4 & 0.85 & 100.94 & 0.85 & 72.59 \\
\hline \multicolumn{5}{|c|}{$\begin{array}{l}\text { Customer-company } \\
\text { identification }\end{array}$} \\
\hline CCID1 & 0.91 & 141.22 & 0.92 & 123.59 \\
\hline CCID2 & 0.86 & 88.22 & 0.90 & 108.87 \\
\hline CCID3 & 0.91 & 122.00 & 0.91 & 98.38 \\
\hline \multicolumn{5}{|c|}{ Information seeking } \\
\hline IS 1 & 0.92 & 140.14 & 0.93 & 155.27 \\
\hline IS 2 & 0.89 & 80.86 & 0.89 & 99.37 \\
\hline IS3 & 0.95 & 164.29 & 0.94 & 230.67 \\
\hline \multicolumn{5}{|c|}{ Information sharing } \\
\hline IF1 & 0.97 & 307.63 & 0.96 & 194.63 \\
\hline IF2 & 0.98 & 411.07 & 0.97 & 328.44 \\
\hline IF3 & 0.97 & 376.93 & 0.97 & 282.83 \\
\hline \multicolumn{5}{|c|}{ Personal interaction } \\
\hline PI1 & 0.92 & 133.01 & 0.89 & 78.33 \\
\hline $\mathrm{PI} 2$ & 0.92 & 136.94 & 0.91 & 115.64 \\
\hline $\mathrm{PI} 3$ & 0.71 & 26.73 & 0.81 & 31.83 \\
\hline PI4 & 0.68 & 24.04 & 0.78 & 27.58 \\
\hline
\end{tabular}




\begin{tabular}{lcccc} 
PI5 & 0.85 & 41.78 & 0.81 & 31.15 \\
Responsible behavior & & & & \\
RB1 & 0.82 & 63.67 & 0.83 & 55.17 \\
RB2 & 0.89 & 108.92 & 0.86 & 47.92 \\
RB3 & 0.86 & 77.04 & 0.87 & 69.28 \\
Advocacy & & & & \\
AD1 & 0.93 & 122.54 & 0.93 & 110.93 \\
AD2 & 0.97 & 357.04 & 0.95 & 136.80 \\
AD3 & 0.95 & 242.55 & 0.93 & 115.43 \\
Helping & & & & \\
HP1 & 0.91 & 141.73 & 0.89 & 74.55 \\
HP2 & 0.90 & 102.39 & 0.87 & 65.53 \\
HP3 & 0.87 & 85.67 & 0.87 & 69.77 \\
HP4 & 0.91 & 109.47 & 0.88 & 69.18 \\
Tolerance & & & & \\
TL2 & 0.95 & 215.07 & 0.95 & 159.46 \\
TL3 & 0.95 & 241.54 & 0.95 & 153.26 \\
Feedback & & & \\
FD1 & 0.86 & 81.24 & 0.82 & 41.77 \\
FD2 & 0.93 & 157.82 & 0.93 & 140.90 \\
FD3 & 0.92 & 143.33 & 0.90 & 93.70 \\
Subjective wellbeing & & & & \\
SWB1 & 0.92 & 134.60 & 0.88 & 49.64 \\
SWB2 & 0.86 & 77.03 & 0.89 & 94.50 \\
SWB3 & 0.92 & 133.89 & 0.89 & 78.14 \\
Respect & & & & \\
PR1 & 0.79 & 68.28 & 0.77 & 41.95 \\
PR2 & 0.91 & 154.51 & 0.89 & 76.48 \\
PR3 & 58.54 & 0.84 & 60.08 \\
\hline & & & & \\
\hline
\end{tabular}


Table 3. Structural model results across contexts

\begin{tabular}{lcccccc}
\hline & \multicolumn{3}{c}{ Australia sample $(n=1323)$} & \multicolumn{4}{c}{ US sample $(n=775)$} \\
\hline & $\mathrm{R}^{2}$ & $\mathrm{Q}^{2}$ & $\mathrm{~F}^{2}$ & $\mathrm{R}^{2}$ & $\mathrm{Q}^{2}$ & $\mathrm{~F}^{2}$ \\
\hline \multicolumn{1}{c}{ Constructs } & & & & & & \\
Perceived service fairness & & & 0.61 & & & 0.60 \\
Trust & 0.29 & 0.19 & 0.30 & 0.35 & 0.22 & 0.33 \\
Customer-company identification & 0.08 & 0.06 & 0.57 & 0.11 & 0.08 & 0.57 \\
Value co-creation behavior & 0.59 & 0.22 & 0.36 & 0.66 & 0.25 & 0.35 \\
Respect & 0.50 & 0.33 & 0.36 & 0.51 & 0.34 & 0.44 \\
Subjective well-being & 0.13 & 0.09 & 0.52 & 0.21 & 0.15 & 0.52 \\
$\quad$ Average & 0.32 & 0.17 & 0.45 & 0.37 & 0.26 & 0.47 \\
$\quad$ GoF & & 0.38 & & & 0.42 &
\end{tabular}

Note: $\mathrm{R}^{2}$ - Variance explained, $\mathrm{Q}^{2}$ - construct cross-validated redundancy, $\mathrm{F}^{2}-$ construct crossvalidated communality.

GoF - Goodness of fit calculated as geometric mean of average $\mathrm{R}^{2}$ and average $\mathrm{F}^{2}$ exceeds threshold level of 0.36 for large effect sizes (Wetzels et al., 2009). 


\begin{tabular}{lcccccc}
\hline \multicolumn{7}{c}{ Table 4. Structural model results across contexts } \\
\hline \multicolumn{1}{c}{ Structural paths } & \multicolumn{2}{c}{ Australia sample } & \multicolumn{2}{c}{ US sample } & \multicolumn{2}{c}{ Comparison } \\
& \multicolumn{2}{c}{$(n=1323)$} & \multicolumn{2}{c}{$(n=775)$} & & \\
& & t-value & $\beta$ & t-value & $\Delta \beta$ & t-value \\
\hline $\mathrm{H}_{1}: \mathrm{PSF} \rightarrow \mathrm{VCCB}$ & 0.37 & 12.26 & 0.34 & 9.87 & 0.03 & 0.59 \\
$\mathrm{H}_{2}: \mathrm{TRU} \rightarrow \mathrm{VCCB}$ & 0.28 & 8.44 & 0.29 & 6.91 & 0.01 & 0.22 \\
$\mathrm{H}_{3}: \mathrm{CCID} \rightarrow \mathrm{VCCB}$ & 0.30 & 9.86 & 0.35 & 9.51 & 0.05 & 1.04 \\
$\mathrm{H}_{4}: \mathrm{PSF} \rightarrow \mathrm{TRU}$ & 0.54 & 22.74 & 0.60 & 20.49 & 0.06 & 1.58 \\
$\mathrm{H}_{5}: \mathrm{PSF} \rightarrow \mathrm{CCID}$ & 0.29 & 10.63 & 0.33 & 9.64 & 0.04 & 1.01 \\
$\mathrm{H}_{6}: \mathrm{VCCB} \rightarrow \mathrm{RES}$ & 0.70 & 41.98 & 0.71 & 31.73 & 0.01 & 0.31 \\
$\mathrm{H}_{7}: \mathrm{VCCB} \rightarrow \mathrm{SWB}$ & 0.34 & 10.08 & 0.43 & 11.89 & 0.09 & 1.84 \\
\hline
\end{tabular}

Note: PSF - perceived service fairness, TRU - trust, CCID - customer-organization identification, VCCB - value co-creation behavior, RES - respect, SWB - subjective wellbeing. 